The Quarterly Journal of Austrian Economics

Volume 23 | No. 2 | 180-191 | SuMmer 2020 WWW.QJAE.ORG

\title{
The Disutility of LABor: A Comment on Fegley and Israel
}

\author{
Joseph T. SALERno*
}

JEL Classification: D01, J01, J20

\begin{abstract}
Aвsтract: Fegley and Israel (2020) have advanced the thesis that the status of leisure as a consumer good is an immediate inference from the action axiom rather than an empirical postulate as maintained by Mises and Rothbard. This comment argues that we can easily imagine a world in which leisure does not represent the opportunity cost of labor, and that Mises and Rothbard have been misconstrued. Additionally, I am strongly unsympathetic to the mode of argument they use in making their case, which is to directly challenge well-established foundational concepts and relations of economic theory. This may only provoke arid quibbling over epistemology.
\end{abstract}

In their article, Tate Fegley and Karl-Friedrich Israel (2020) make two bold and sweeping claims. The first concerns the foundations of praxeology, the method of Austrian economics. Their second pertains to a different sphere altogether, that of "economic semantics" (Machlup 1967). Both spheres of inquiry are important in the development of economic theory, but it is crucial to maintain strict separation between them. Fegley and Israel $(2020,46)$ state their claims as follows:

\footnotetext{
*Joseph T. Salerno (salerno@mises.org) is academic vice president of the Mises Institute and John V. Denson II Endowed Professor in the Department of Economics at Auburn University.
} 
[1.] Leisure (the state of not engaging in labor) is a necessary complementary good for consuming other goods. As such, leisure's status as a consumer good is a priori true, not an empirical assumption. [2.] Furthermore, the concept of disutility of labor is not only unnecessary but also leads to confusion due to its being used in two different ways, and therefore ought to be discarded.

Unfortunately, the discussions of these two propositions are confusingly entwined throughout the article although they have no logical connection to one another. For the sake of conceptual clarity, I will analyze each proposition separately. I will begin with proposition 1, which is more important because it cuts to the heart of the praxeological method, which is the method of imaginary constructions, "the specific method of economics" (Mises [1949] 1998, 237).

Fegley and Israel contend that the proposition "leisure is a consumer good" is not an empirical postulate supplementing the action axiom. Rather, they argue, like the concepts of means and ends or uncertainty, it is an immediate inference of the axiom. This is tantamount to denying that a world can be conceived in which acting beings do not experience disutility of labor and, therefore, always expend their full capacity to work. This denial underlies their claim that labor always involves an inherent opportunity cost. As Fegley and Israel $(2020,51)$ state their argument:

\footnotetext{
Contrary to what Mises and Rothbard argue, we cannot without contradiction conceive of a world in which... engaging in labor has no opportunity cost. Hence, it is not really an additional assumption that supplements otherwise a priori praxeological theory, but rather an aspect of it that is already implied in the concept or axiom of action. Any specific course of action, be it classified as labor or leisure, has opportunity costs, as the choice of one action presupposes alternatives that must be forgone.
}

In fact, as I will argue, we can easily imagine a world in which leisure does not represent the opportunity cost of labor. However, the authors preempt the conception of such a world by a semantic sleight of hand. After initially defining leisure as "the absence of labor," Fegley and Israel $(2020,48)$ subtly change their definition a sentence later. They first cite Mises's definition of labor as "the employment of the physiological functions and manifestations of 
human life as a means" (Mises [1949] 1998, 131). They then assert that leisure as "the absence of labor" can "alternatively" be defined as "the employment of the physiological functions and manifestations of human life as an end." From this they infer that "leisure is not only the act of 'doing nothing,' but the use of one's body for consumption, rather than production." And voilà, leisure is always and everywhere a consumer good and, therefore, labor bears an intrinsic opportunity cost.

Fegley and Israel believe that they have demonstrated aprioristically that leisure is a consumer good and labor always incurs an opportunity cost in terms of foregone leisure. But they have done no such thing. They have stated two premises:

1. Leisure is the absence of labor.

2. Labor is a means to an end and requires the use of one's body.

From these two premises they claim to have logically deduced that leisure is the use of one's body as an end and, therefore, that there is a tradeoff between time devoted to production and time devoted to consumption. For this syllogism to hold true, however, other-empirical-postulates are required relating to the human body, whose functions, capacities, and limitations are a datum for economic theory and closed to praxeological inquiry. This was clearly spelled out by Mises ([1949] 1998, 11, 642):

\footnotetext{
The unconscious behavior of the bodily organs and cells is for the acting ego no less a datum than any other fact of the external world. Acting man must take into account all that goes on within his own body as well as other data.... Praxeology deals with human action as such in a general and universal way. It deals neither with the particular conditions of the environment in which man acts nor with the concrete content of the valuations which direct his actions. For praxeology data are the bodily and psychological features of the acting men, their desires and value judgments, and the theories, doctrines, and ideologies they develop in order to adjust themselves purposively to the conditions of their environment and thus to attain the ends they are aiming at. (emphasis added)
}

Mises $(2003,16)$ specifically argued that praxeology may assume as a datum a human body with radically different features, limitations, and capabilities than exist in reality. For example, it may assume that "men lacked the possibility of understanding one another by means 
of symbols" or that they were "immortal and eternally young" and therefore "indifferent in every respect to the passage of time." Indeed, according to Mises (15-16), it is possible to construct "a universal praxeology so general that its system would embrace not only all the patterns of action in the world that we actually encounter, but also patterns of action in worlds whose conditions are purely imaginary and do not correspond to any experience. The axioms of the theory could conceivably be framed in such universal terms as to embrace these and all other possibilities." For Mises, the economist does not undertake such a project "because conditions that do not correspond to those we encounter in our action interest us only in so far as thinking through their implications in imaginary constructions enables us to further our knowledge of action under given conditions" (16).

This leads us to the question of whether we can imagine a world in which the physical bodies or psychological makeup of acting beings is such that they experience no disutility of labor? If the answer to this is yes, then Fegley and Israel have failed to prove their thesis that "leisure's status as a consumer good is a priori true, not an empirical assumption."

Let us first imagine a world in which all persons fully exhaust their capacity for productive labor after a certain period of time. They then enter a state of leisure, i.e., "absence of labor," during which time they engage in what Mises called "recreation and restoration of the capacity to work." We assume that during this time they are physically able to pursue various consumption goals. We further assume that every person's consumption goals consistent with his stocks of goods and intertemporal consumption preferences are achievable within the state of leisure. Given these empirical assumptions-none of which contradict the action axiomlabor does not have an opportunity cost or disutility in terms of consumption foregone. The amount of leisure time is not chosen by the actor but imposed on him by the physiological requirements of his body and is superabundant with respect to his consumption goals. Leisure therefore has no value as a complementary input to the enjoyment of consumer goods. In the real world, these assumptions approximate the behavior of the "workaholic." For example, the tech billionaire works to the point of exhaustion of his physical or mental labor capacity and then enjoys driving his Lamborghini home to consume a sumptuous meal prepared by a 
first-class private chef, after which he watches a movie in his private screening room, contemplates the fine art in his gallery, buys stuff online, and gets a few hours' sleep.

Another hypothetical world in which leisure is not a consumer good is one in which the human body is imagined to have the capacity to process all conceivable consumption enjoyments while simultaneously expending maximum productive effort. In this imaginary construct "the state of not engaging in labor" is not required to achieve consumption goals and therefore labor has no opportunity cost. This has a parallel in our world with the consummate multi-tasker: the venture capitalist who can negotiate and close deals while sipping a martini and smoking a cigar on his yacht or the office worker who eats, uses social media, and gambles online while working hard in her cubicle. Actually, there are people who work twenty-four hours per day, seven days per week while managing to consume. A quick search of the internet reveals dozens and dozens of pornographic subscription websites on which people can literally be viewed " $24 / 7$ " engaging in all kinds of activities via webcams strategically placed throughout their living spaces.

If one does not fancy these constructions, one can conjure up fictional worlds in which action is possible even further removed from our own. We can assume that the productive capabilities of the actors' bodies are catalyzed by daylight while their capacity to consume lies dormant until the sun sets. Alternatively, it is conceivable all people choose to only work from sun rise to sunset and only consume after dark for religious, cultural, or psychological reasons. Letting our imagination range further afield, we may even suppose that an acting ego has control of two physical bodies: one specifically equipped solely for labor and the other solely for consumption activities.

It is evident that none of these imaginary constructions preclude the possibility of action, of the purposive use of means to attain ends. In all of them, there exist-that is, we cannot contemplate them without also thinking of-the means-end distinction, scarcity, uncertainty, the value scale, choice, and the other fundamental concepts and laws of human action. ${ }^{1}$ Yet in none of these

\footnotetext{
${ }^{1}$ As Mises $(2003,15)$ pointed out, "we are quite incapable of thinking of this fundamental category [of action] and the system deduced from it without also thinking, at the same time, of the universal prerequisites of human action. For example,
} 
constructions is leisure valued by the actor as a final consumer good or as a "complementary good for consuming other goods." Therefore, "leisure's status as a consumer good" is not an a priori inference from action but is established by empirical insight into the concrete conditions of action. Fegley and Israel (2020, 52) seem to glimpse the truth that the value of leisure depends on the assumption of definite empirical conditions:

Only if it is the case that there is no necessary relationship and one can engage in all types of consumption he or she desires without ceasing to labor, could it be possible at all that individuals would supply all the labor of which they are physically capable of providing. Only under such conditions would there be no opportunity cost, in terms of forgone consumption, to engaging in labor.

Unfortunately, at this critical point, the authors seem to experience a failure of imagination and stop short of spelling out the exact conditions under which labor would have "no opportunity cost in terms of forgone consumption" (52). Instead they resort to an assertion of what they have set out to prove, "the action axiom implies that the use of the human body is scarce and one must prioritize among ends." But the action axiom does not imply that the human body is scarce in all its capacities and functions, no more than it implies that all kinds of land are scarce. The action axiom implies only that means are scarce in relation to ends. Exactly what those means are is a matter for empirical investigation. We can certainly conceive a world in which actors' bodies are superabundant in relation to land. Imagine actors who have the ability to instantly replicate their bodies and, therefore, their capacity to work and consume, an endless number of times. However, assuming land and capital are scarce, doing so would drive the marginal product of labor to zero or below and, at this point, additional bodies would not increase income or consumption. In this world, the value of an extra human body would therefore be zero. Although the human body would not be scarce, actors would "still have to prioritize among ends," because

we are unable to grasp the concept of economic action and of economy without implying in our thought the concept of economic quantity relations and the concept of an economic good." 
the scarcity of natural resources and capital goods would limit the supplies of consumer goods. Hence, the potentialities and limits of the human body are particular conditions of action that can only be learned by experience, not praxeological reasoning.

It actually is not necessary to construct fictional worlds to criticize Fegley and Israel's argument, although it is a useful heuristic exercise to vividly differentiate between praxeological theory and the concrete data that ground such reasoning in the reality of our world. We can also challenge their argument by citing a theorem widely accepted by Austrian economists which assumes in its derivation a perfectly inelastic general supply of labor, i.e., the absence of the disutility of labor. The authors can then be called upon to demonstrate where the theorem fails because it is based on an assumption that contradicts the action axiom. One such theorem is that net saving in the economy "lengthens" the structure of production and raises the real wage rates of laborers. This theorem was given its most extensive development by Friedrich Hayek ([1935] 2008, 223-52) and Murray Rothbard ([1962, 1970] 2009, 517-43), whose analyses were very similar.

Hayek ([1935] 2008, 225-27) began his analysis from a "stationary state" in which the supplies of all resources are fixed and fully employed. His purpose was to show that an increased "output of consumers' goods from a given quantity of original means of production" results from "transition to more capitalistic methods of production." Hayek ([1935] 2008, 237-39) then demonstrated how a change in "the volume of voluntary saving" causes an increase in "the average length of the roundabout processes of production." Once the transition to the lengthened structure of production has been completed, a new equilibrium ensues in which "the amount of original means of production [i.e., land and labor] used has remained the same" while the quantities of capital and consumer goods have increased (emphasis added). The prices of consumer goods therefore fall relative to the prices of the original factors, particularly labor, and real wages accordingly increase. But if the quantity of labor "has remained the same" in the new equilibrium despite higher real wage rates, then it means that Hayek has deduced his theorem with the assumption of a perfectly inelastic general supply curve for labor and hence has assumed that leisure is not a consumer good. In discussing 
the "effect of net investment" on the economy, Rothbard makes the same assumption and reaches the same conclusion as Hayek. ${ }^{2}$

Now if Hayek and Rothbard's theorem is based on an assumption that contradicts the action axiom, then it should conflict with other theorems in the chain of praxeological deductions and it could readily be proven false. The same could be said of the opportunity cost doctrine itself, which Fegley and Israel make extensive use of. In a famous article, Lionel Robbins ([1930] 1997, 72) articulated the crucial difference in assumptions underlying the controversy that took place during the period between 1890 and 1910 over the question: "Are all costs ultimately resolvable into foregone products, or are labor-pain and abstinence to be regarded as ultimate?" On one side of this "battle of giants" were arrayed the opportunity-cost theorists led by Böhm-Bawerk, Wieser, Wicksteed, and Davenport; on the other, stood the British economists Marshall and Edgeworth, who upheld the real-cost doctrine. Robbins perceptively pointed out that the debate turned on the different forms of the supply functions for labor and capital assumed by each side. Böhm-Bawerk et al. made the simplifying empirical assumption that labor and capital supply curves were perfectly inelastic, while Marshall and Edgeworth, in a quest for greater "realism," assumed upward-sloping supply curves. As it turned out, it was easier to initially derive the opportunity cost doctrine with the aid of the simplified assumptions and then apply the doctrine to the realistic case of elastic supply curves.

If Fegley and Israel are truly interested in proving the a priori nature of the proposition that leisure is a consumer good, I suggest that they show the errors and contradictions in the praxeological theorems deduced using the antithetical proposition. Such an endeavor is potentially much more useful to the development of economic theory than advancing yet another hair-splitting argument about the epistemological status of the fundamental concepts and relationships from which the theory is deduced.

Let me now make a few brief remarks regarding Fegley and Israel's contention that the concept of the disutility of labor is "not

\footnotetext{
${ }^{2}$ Indeed, Rothbard ([1962, 1970] 2009, 453-507, 572-78) does not introduce upwardsloping general supply curves for labor in his discussion of net investment or his analysis of general factor pricing.
} 
only unnecessary but also leads to confusion due to its being used in two different ways." The authors cite the usage of the term by Percy Greaves, Mises, and Rothbard. I will focus on their criticisms of the latter two. The authors' main critique of Mises is that in several passages he implies that "the disutility of labor is... a psychological phenomenon, an obstacle to be 'overcome,' rather than merely the opportunity cost of engaging in labor" (Fegley and Israel 2020, 49).

In one passage Mises ([1949] 1998, 585) states, "the disutility of labor in itself-not its product-satisfies." The authors find this statement "utterly confusing" and interpret it as meaning that "the disutility of labor is not the utility of leisure foregone, but the pain, discomfort, or unpleasantness of engaging in labor." But Mises makes this statement in his discussion of introversive labor, in which labor is undertaken as an end in itself. For Mises (484-85), introversive labor qualifies "as consumption," and he suggests three motives for it. Let us take the example of a tennis player to illustrate these motives. First, he may play tennis with friends on weekends to maintain health and vitality and strengthen his body. Second, he may play tennis with disadvantaged children in order to serve God in compliance with his religious duties and his quest for eternal bliss. And, third, he may absorb himself in playing tennis to forget distressing events, ward off depression, or lift his spirits. In all of these cases it is the very disutility of labor, the very sacrificing of leisure, which serves as its own reward. Furthermore, Mises views leisure along an intensive as well as an extensive margin. Thus the more intense the labor, the greater is the sacrifice of leisure and, hence, the greater is the reward. ${ }^{3}$ In Mises's example of the mountain climber: "The toil of climbing...involves disutility of labor. But it is precisely overcoming the disutility of labor that satisfies him. A less exerting [i.e., less leisurely] ascent would not please him better but less."

Now, in contrast to Fegley and Israel (2020,49), I do not find Mises's usage of the term "disutility of labor" at all confusing in this context. Nor do I share the authors' confusion concerning the implication that "'disutility' can generate something like 'utility'"

\footnotetext{
${ }^{3}$ With respect to "extroversive" labor in exchange for wages, the disutility of labor can be reduced on the intensive margin by what economists refer to as "shirking" or what used to be called in the vernacular "loafing" or "goofing off" on the job.
} 
(ibid.). All disutility generates utility; otherwise it would not be voluntarily incurred by purposeful beings. The disutility of "extroversive" labor provided on the market generates the utility of a market wage rate, just as the disutility of playing tennis with less fortunate children produces the utility of complying with one's religious duties. I also think that the authors' concern about the psychological connotation of Mises's term "overcome" with respect to disutility of labor is misplaced. In the very first sentence of his discussion of the topic, Mises ([1949] 1998, 584) uses the phrase "overcome the disutility of labor" followed immediately by the parenthetical clarification, "forego the enjoyment of leisure."

Fegley and Israel (2020, 49-50) also find fault with Mises's discussion of "the joy and tedium of labor." They seize on the following statement: "Having completed a task the worker enjoys the feeling of having successfully overcome all the toil and trouble involved. He is happy in being rid of something difficult, unpleasant, and painful, in being relieved for a certain time of the disutility of labor" (Mises [1949] 1998, 586). They claim that Mises here "identifies the disutility of labor with unpleasantness, rather than strictly the opportunity cost of forgone leisure." Their claim fails, however, because Mises is here referring to "special emotional phenomena [that] sometimes appear, feelings of joy or tedium, accompanying the execution of certain kinds of labor." Mises is careful to specify that such feelings "are in a domain other than the disutility of labor... [and] therefore can neither alleviate nor remove the disutility of labor." In other words, the disutility of labor lies in the praxeological realm and therefore influences choice and action. The joy and tedium of labor are emotional reactions to choices made and, as an ex post factor, they influence neither the choice of whether to incur the disutility of labor nor the value of the product or disutility of labor. Mises ([1949] 1998, 588) is clear and emphatic on this point:

The fact that the tedium of labor is substituted for the joy of labor [by ideological influences] affects the valuation neither of the disutility of labor nor of the produce of labor. Both the demand for labor and the supply of labor remain unchanged.... What is altered is merely the worker's emotional attitude.

Whatever one thinks of Mises's psychological conception of the joy and tedium of labor, Mises leaves no doubt that it is completely 
distinct from the praxeological conception of labor's disutility and that the only "pain" associated with the latter conception is the loss of satisfaction attending the sacrifice of a given quantity of leisure. For Mises "disutility" is purely a convenient accounting term. Every product of an act of labor is credited with a gain in utility on the revenue account of the individual's "psychic" income statement and debited either with a loss of utility (opportunity cost of leisure forgone) or with the incurring of disutility (opportunity cost of leisure forgone) on the cost account. Psychic profit (or loss) is the same in either case. Because forgoing leisure is a (potential) opportunity cost of every act of labor, it is expedient to denote it with a general term and treat it positively as a cost item incurred when discussing the overall labor-leisure tradeoff. On the other hand, when we are conceiving of an actor as choosing among different employments, it is easier to debit psychic cost with the lost utility of the specific forgone money income and positive nonpecuniary components (shorter commute, more aesthetic work space, etc.) from the next best employment opportunity. If there are relatively disagreeable psychic components attaching to a job such as the forgone utility of healthful air and of freedom from perceived risk of being buried alive, which is experienced by subterranean miners, then it is perfectly correct to combine these specific opportunity costs with forgone leisure and treat them as part of the disutility of labor. The authors' criticism of Rothbard for including "the disagreeable conditions under which labor is performed as part of what constitutes the disutility of labor" is thus groundless (Fegley and Israel 2020, 50).

I do not think that Fegley and Israel have proven their thesis that the status of leisure as a consumer good is an immediate inference from the action axiom rather than an empirical postulate as maintained by Mises and Rothbard. More important, I am strongly unsympathetic to the mode of argument they use in making their case, which is to directly challenge well-established foundational concepts and relations of economic theory. This is unlikely to be of much interest to working Austrian economists and, at best, will provoke arid quibbling over epistemology. A much more effective and fruitful approach would be to identify several economic theorems much further down the chain of praxeological deductions and demonstrate that they are false because they crucially depend 
upon an assumption that contradicts the action axiom, namely, that leisure is not a valuable consumer good. Indeed, one need not go searching for such false and contradictory theorems; if they exist, they will inevitably come to light during the work of applying praxeological theorems to explaining real-world economic events. This is the way that praxeological theory progresses. Regarding the authors' subsidiary thesis that the concept of the disutility of labor should be discarded as unnecessary and because it is used by Mises and Rothbard in two different senses, I find no merit in this contention. Mises and Rothbard are crystal clear in what they mean by the concept and, although not absolutely necessary, the concept is expedient for certain problems in economic theory.

\section{REFERENCES}

Fegley, Tate, and Karl-Friedrich Israel. 2020. "The Disutility of Labor." Quarterly Journal of Austrian Economics 23, no. 2: 171-179.

Hayek, F. A. [1935] 2008. Prices and Production. In Prices and Production and Other Works: F. A. Hayek on Money, the Business Cycle, and the Gold Standard, ed. Joseph T. Salerno. Auburn, Ala.: Ludwig von Mises Institute.

Machlup, Fritz. 1967. Essays in Economic Semantics. Ed. Merton H. Miller. New York: W. W. Norton and Company, Inc.

Mises, Ludwig von. [1949] 1998. Human Action: A Treatise on Economics. Scholar's Edition. Auburn, AL: Mises Institute.

- 2003. Epistemological Problems of Economics. Trans. George Reisman. 3d ed. Auburn, Ala.: Mises Institute.

Robbins, Lionel. [1930] 1997. "On a Certain Ambiguity in the Conception of Stationary Equilibrium." In Economic Science and Political Economy: Selected Articles, ed. Susan Howson. New York: New York University Press.

Rothbard, Murray N. $[1962,1970]$ 2009. Man, Economy, and State with Power and Market. 2d scholar's ed. Auburn, Ala.: Ludwig von Mises Institute. 